\title{
Natural Chlorins Modified with Cholesterol Moiety. Synthesis, Characteristics, Copper Complexes, and Entrapping in Phospholipid Vesicles
}

\author{
Irina A. Nikolaeva, ${ }^{a}{ }^{2}$ ulia V. Morozova, ${ }^{a}$ Maria G. Zavialova, ${ }^{a}$ Roman A. Novikov, ${ }^{\text {b }}$ \\ Yaroslav V. Tkachev, ${ }^{\text {b }}$ Vladimir P. Timofeev, ${ }^{\text {b }}$ Alexander Yu. Misharin, ${ }^{\mathrm{a}}$ \\ and Gelii V. Ponomareva@
}

${ }^{a} V . N$. Orekhovich Institute of Biomedical Chemistry RAMS, 119121 Moscow, Russia

${ }^{\mathrm{b}} V$. A. Engelhardt Institute of Molecular Biology RAS, 119991 Moscow, Russia

${ }^{\circledR}$ Corresponding author E-mail: gelii@yandex.ru

\begin{abstract}
The chemical synthesis and characteristics of two natural chlorins modified with cholesterol moieties: 17" [(cholest5-en)-3 $\beta$-yloxyethoxycarbamoyl]pyropheophorbide $a$ and 13'[(cholest-5-en)-3b-yloxyethoxycarbamoyl]chlorin are presented, as well as the preparation of the related copper complexes. Both conjugates obtained, as well as their copper complexes, may be simply incorporated in phosphatidylcholine vesicles. Being entrapping in vesicles all these conjugates are considered to be novel potential sensitizers for photodynamic therapy, while copper complexes of conjugates are considered to be spin probes for membrane studies, providing important structural and dynamical information.
\end{abstract}

Keywords: Chlorins, cholesterol derivatives, bioconjugates.

\section{Introduction}

Tetrapyrrolic macrocyles, owing to their unique spectral, photochemical, photophysical, and metal chelating properties have a wide range of biomedical applications, such as optical imaging, fluorescent labeling, photodynamic inactivation of microbial infections, and photodynamic therapy of solid tumors. ${ }^{[1-6]}$ A key challenge to the implementation of tetrapyrrolic macrocyles for biomedicine entails tailoring the molecules either with hydrophilic substituents to achieve its water solubility, ${ }^{[7,8]}$ or with lipophylic substituents for the incorporation into liposomes and lipid micelles. ${ }^{[9,10]}$ Coupling of phthalocyanine and pyropheophorbide macrocycles with estradiol and $3 \beta$-oleoyloxyanrost-5-en-17-amine was shown to be an efficient approach for the receptor-dependent targeting of macrocycles to cells. ${ }^{[11,12]}$

We hypothesized that modification of tetrapyrrolic macrocycle with lipophylic cholesterol moiety may be of interest, since cholesterol is essential component of mammalian membranes. The resulting conjugates are thought to have affinity to phospholipids and may be used as photosensitizers entrapped in liposomes. Insertion of paramagnetics into the coordination sphere of macrocycle may convert them to spin probes suitable for membrane studies. Moreover, modification of various macrocycles with cholesterol fragments in different positions results in conjugates differing in chemical structure and properties, and, probably, in biomedical applications.

Our preliminary communication concerning first synthesis of chlorin $e_{6}$ - cholesterol conjugate was reported recently. ${ }^{[13]}$ The goal of the present study is elaboration of method for introducing of cholesterol fragment either in 13', or in 17" positions of macrocycle through short aminoethoxy spacer; chemical synthesis and characterization of two conjugates $\mathbf{1}$ and $\mathbf{2}$, in which either pyropheophorbide, or chlorin $e_{6}$ moieties are connected with cholesterol by formation of amide bonds; preparation and characterization of the related copper complexes; evaluation of entrapping

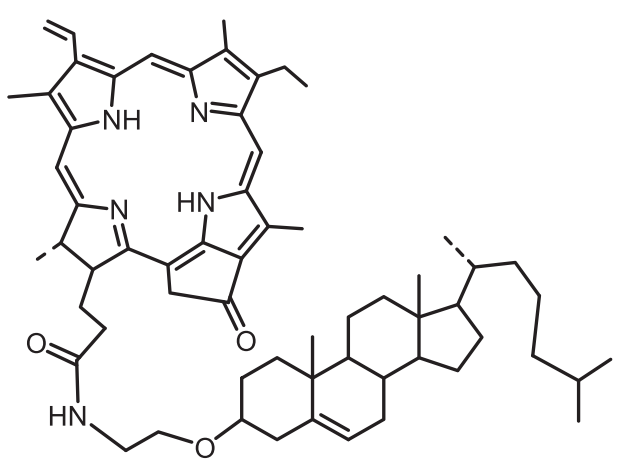

1

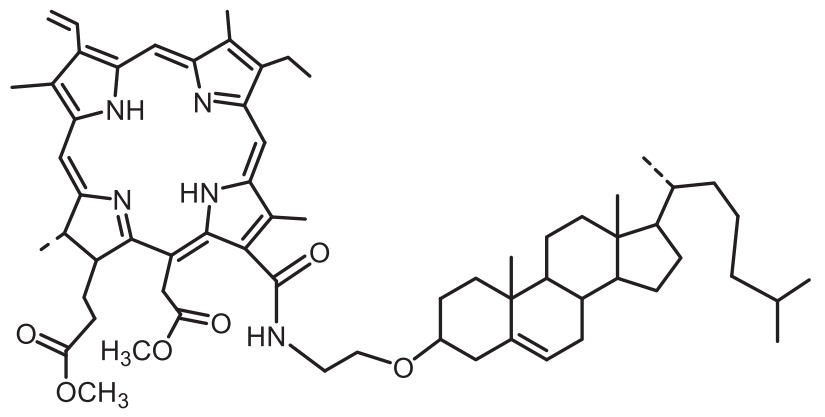

2 
of conjugates $\mathbf{1}$ and $\mathbf{2}$ and their copper complexes to phospholipids vesicles; and their preliminary testing as membrane spin probes.

\section{Experimental}

Reagents and solvents were obtained from "Aldrich" "Sigma", "Acros Organics" and "Ekos-1 Ltd"; methyl pheophorbide, 3, isolated from Spirulina platencis according to ${ }^{[14]}$, and $3 \beta(2-$ hydroxyethoxy)-cholest-5-ene, 7, synthesized according to the published procedure, ${ }^{[15,16]}$ were used as the starting compounds.

Absorption spectrum were registered on a 'Thermospectronic Helios $\alpha$ ' spectrophotometer; ${ }^{1} \mathrm{H}$ NMR and ${ }^{13} \mathrm{C}$ NMR spectra were registered on an 'AMX-III' $400 \mathrm{MHz}$ Bruker instrument in $\mathrm{CDCl}_{3}$; high resolution mass spectra (HMRS) were registered on a Bruker 'Apex Ultra' FT ICR MS instrument at ion positive electro spray ionization mode; EPR spectra were registered on a Varian E-104 X-band $(9.15 \mathrm{GHz})$ spectrometer at room temperature $(293 \mathrm{~K})$, with microwave irradiation level of $20 \mathrm{~mW}$, modulation amplitude of $4 \mathrm{G}$ and sweep width of $1000 \mathrm{G}$.

Melting points (m.p.) of crystalline compounds were measured in a glass capillary. Analytical TLC was performed on "HPTLC Kieselgel UV-254" plates from "Merck" using the following systems - A: hexane - EtOAc (19:1); B: hexane - EtOAc (7:1); C: $\mathrm{CHCl}_{3}-\mathrm{MeOH}-\mathrm{AcOH}$ (85:14:1); D: $\mathrm{CH}_{2} \mathrm{Cl}_{2}-\mathrm{MeOH}$ (99:1), E: $\mathrm{CH}_{2} \mathrm{Cl}_{2}-\mathrm{MeOH}(19: 1)$; visualization of spots was carried out by UV-lamp $(254 \mathrm{~nm})$, by spraying either with $3 \%$ ammonium molybdate in $5 \%$ sulfuric acid, or with $0.2 \%$ ninhydrin solution in a mixture of $\mathrm{EtOH}: \mathrm{AcOH}: 2,4,6$-collidine (19:1:1), followed by heating. Flash column chromatography was performed on silica gel $(40-63 \mu \mathrm{m})$ from "Merck".

Methyl pyropheophorbide $a, 4$. The solution of methylpheophorbide $3(1.00 \mathrm{~g}, 1.65 \mathrm{mmol})$ in $50 \mathrm{ml}$ of dry pyridine (Py) was heated under reflux for $8 \mathrm{~h}$, thereafter the solution was poured into $200 \mathrm{ml}$ of ice water. The precipitate was filtered, dried in air, the target compound $4(0.81 \mathrm{~g}, 1.48 \mathrm{mmol}, 90 \%)$ was isolated by silica gel column chromatography in $\mathrm{CH}_{2} \mathrm{Cl}_{2}-\mathrm{Et}_{2} \mathrm{O}$ (19:1) mixture. Characteristics of the obtained preparation were completely congruent to those reported previously. ${ }^{[17]}$

Pyropheophorbide $a, 5$. The solution of methyl pyropheophorbide $a \mathbf{4}(215 \mathrm{mg}, 0.39 \mathrm{mmol})$ in $50 \mathrm{ml}$ of $50 \%$ sulfuric acid was stirred for $2 \mathrm{~h}$ at room temperature, then $100 \mathrm{~g}$ of chopped ice was added, the mixture was neutralized with aqueous ammonia, the obtained precipitate was collected by filtration, and dried in vacuo to give target compound $\mathbf{5}$ in near quantitative yield (203 $\mathrm{mg}, 0.38 \mathrm{mmol})$. HRMS, calculated for $\left[\mathrm{C}_{33} \mathrm{H}_{35} \mathrm{~N}_{4} \mathrm{O}_{3}\right]^{+}: 535.2709$; found: 535.2711. ${ }^{1} \mathrm{H}$ NMR $\delta_{\mathrm{H}}$ ppm: $-1.70(\mathrm{br} . \mathrm{s}, 1 \mathrm{H}, \mathrm{NH}) ; 1.65(\mathrm{t}$, $\left.J=7.8 \mathrm{~Hz}, 3 \mathrm{H}, \mathrm{CH}_{3} \mathrm{CH}_{2} \mathrm{C}=\right), 1.80\left(\mathrm{~d}, J=7.3 \mathrm{~Hz}, 3 \mathrm{H}, \mathrm{CH}_{3} \mathrm{CH}\right)$, $3.17,3.36,3.60\left(\right.$ each s, $\left.3 \mathrm{H}, \mathrm{CH}_{3} \mathrm{CC}=\right), 4.28$ (br. d, $J=9.0 \mathrm{~Hz}$ ), $4.45\left(\mathrm{qd}, J=7.4 \mathrm{~Hz}\right.$ and $\left.J=1.8 \mathrm{~Hz}, 1 \mathrm{H}, \mathrm{CH}_{3} \mathrm{CHCH}\right), 5.08,5.23$ (each d, $J=19.8 \mathrm{~Hz}, 1 \mathrm{H}, \mathrm{CCH}_{2} \mathrm{COO}$ ), $6.13(\mathrm{dd}, J=11.7 \mathrm{~Hz}$ and $J=1.4 \mathrm{~Hz}, 1 \mathrm{H}, H_{2} \mathrm{C}=\mathrm{CH}$, trans $), 6.24(\mathrm{dd}, J=17.9 \mathrm{~Hz}$ and $J=1.4$ $\left.\mathrm{Hz}, 1 \mathrm{H}, H_{2} \mathrm{C}=\mathrm{CH}, c i s\right), 7.93(\mathrm{dd}, J=11.5 \mathrm{~Hz}$ and $J=17.9 \mathrm{~Hz}, 1 \mathrm{H}$, $\mathrm{H}_{2} \mathrm{C}=\mathrm{C} H$ ), 8.51, 9.29, 9.40 (each s, $1 \mathrm{H}, \beta-\mathrm{H}, \mathrm{CHC}=$ ). ${ }^{13} \mathrm{C} \mathrm{NMR} \delta_{\mathrm{c}}$ ppm: 11.26, 12.07, 12.13, 17.46, 19.51, 23.20, 29.74, 30.79, 48.08, $50.08,51.68,93.08,97.23,104.16,106.09,122.55,128.38,129.29$, $130.46,131.67,135.94,136.12,136.35,137.92,141.69,145.06$, $149.14,150.87,155.37,160.29,171.45,177.38,196.51$. UV-vis $\left(\mathrm{CH}_{2} \mathrm{Cl}_{2}\right) \lambda_{\max }$ nm: 398, 498, 660 .

Pentafluorophenyl pyropheophorbide a, 6. Pyropheophorbide a 5 (150 mg, $0.28 \mathrm{mmol}$ ) was dissolved in $15 \mathrm{ml}$ of $\mathrm{CH}_{2} \mathrm{Cl}_{2}$, then pentafluorophenyl trifluoroacetate $(0.3 \mathrm{ml}, 1 \mathrm{mmol})$ was added, thereafter $\mathrm{Et}_{3} \mathrm{~N}(0.6 \mathrm{ml})$ was added dropvise to stirred solution during 10-15 min, the formation of product 6 being controlled by TLC. After the reaction was completed, the solvent was evaporated in vacuo, the residue was twice reevaporated with hexane, and purified by chromatography on silica gel in hexane to give pentafluorophenyl pyropheophorbide $a \mathbf{6}$ in quantitative yield (195 mg, $0.28 \mathrm{mmol}$,). HRMS, calculated for $\left[\mathrm{C}_{39} \mathrm{H}_{34} \mathrm{~F}_{5} \mathrm{~N}_{4} \mathrm{O}_{3}\right]+$ : 701.2551; found: 701.2565. ${ }^{1} \mathrm{H}$ NMR $\delta_{\mathrm{H}} \mathrm{ppm}: 1.68(\mathrm{t}, J=7.6 \mathrm{~Hz}$, $\left.3 \mathrm{H}, \mathrm{CH}_{3} \mathrm{CH}_{2} \mathrm{C}=\right), 1.84\left(\mathrm{~d}, J=7.3 \mathrm{~Hz}, 3 \mathrm{H}, \mathrm{CH}_{3} \mathrm{CH}\right), 3.21,3.40,3.64$ (each s, $3 \mathrm{H}, \mathrm{CH}_{3} \mathrm{CC}=$ ), 4.36 (br. d, $\left.J=9.0 \mathrm{~Hz}\right), 4.52$ (qd, $J=7.3 \mathrm{~Hz}$ and $\left.J=1.9 \mathrm{~Hz}, 1 \mathrm{H}, \mathrm{CH}_{3} \mathrm{CHCH}\right), 5.18,5.24$ (each d, $J=19.7 \mathrm{~Hz}, 1 \mathrm{H}$, $\left.\mathrm{CCH}_{2} \mathrm{COO}\right), 6.17\left(\mathrm{dd}, J=11.5 \mathrm{~Hz}\right.$ and $J=1.4 \mathrm{~Hz}, 1 \mathrm{H}, \mathrm{H}_{2} \mathrm{C}=\mathrm{CH}$, trans), 6.27 (dd, $J=17.9 \mathrm{~Hz}$ and $J=1.4 \mathrm{~Hz}, 1 \mathrm{H}, \mathrm{H}_{2} \mathrm{C}=\mathrm{CH}$, cis), $7.97\left(\mathrm{dd}, J=11.5 \mathrm{~Hz}\right.$ and $\left.J=17.9 \mathrm{~Hz}, 1 \mathrm{H}, \mathrm{H}_{2} \mathrm{C}=\mathrm{CH}\right), 8.55,9.35$, 9.46 (each s, $1 \mathrm{H}, \beta-\mathrm{H}, \mathrm{CHC}=$ ). ${ }^{13} \mathrm{C}$ NMR $\delta_{\mathrm{C}}$ ppm: $11.28,12.12$, 17.44, 19.53, 23.14, 29.72, 30.32, 47.99, 50.01, 51.41, 93.05, 97.41, $104.40,105.98,122.76,128.57,129.23,130.37,131.83,136.17$, $136.27,136.54,136.71,136.83,137.99,138.38,139.25,139.92$, $140.90,141.92,142.47,145.27,149.23,151.02,155.65,159.57$, 169.17, 177.30, 196.55. UV-vis $\left(\mathrm{CH}_{2} \mathrm{Cl}_{2}\right) \lambda_{\max } \mathrm{nm}: 398,498,660$.

$3 \beta$-(2-Toluenesulfonyloxyethoxy)cholest-5-ene, $8 . \quad$ Sterol 7 (3.23 g, $7.5 \mathrm{mmol})$ was dried by evaporation with abs. Py and dissolved in $20 \mathrm{ml}$ of abs. Py. TsCl (1.91 g, $10 \mathrm{mmol})$ was added to the obtained solution, and the mixture was stirred for $8 \mathrm{~h}$ at room temperature; thereafter it was poured into the mixture consisted of $150 \mathrm{ml} \mathrm{NaHCO}$ saturated solution and $50 \mathrm{~g}$ of chopped ice. The resulting mixture was stirred for $2 \mathrm{~h}$, filtered and the residue was dissolved in $50 \mathrm{ml}$ of benzene. The obtained solution was repeatedly washed with $3 \% \mathrm{HCl}$ solution $(2 \times 20 \mathrm{ml})$, water $(2 \times 30 \mathrm{ml})$, dried over $\mathrm{Na}_{2} \mathrm{SO}_{4}$, evaporated to dryness and recrystallized from hexane to give $3.90 \mathrm{~g}(6.69 \mathrm{mmol}, 89 \%)$ of tosylate $\mathbf{8}$ as white needles with m. p. $115^{\circ} \mathrm{C} .{ }^{1} \mathrm{H}$ NMR $\delta_{\mathrm{H}}$ ppm: 0.67 (s, $\left.3 \mathrm{H}, \mathrm{H}-18\right), 0.85$ and 0.86 (each d, $J=6.6 \mathrm{~Hz}, 3 \mathrm{H}, \mathrm{H}-26$ and $\mathrm{H}-27), 0.91$ (d, $3 \mathrm{H}, J=6.6 \mathrm{~Hz}$, $\mathrm{H}-21), 0.96$ (s, 3H, H-19), 2.43 (s, 3H, $\mathrm{CH}_{3}$, tosyl), 3.09 (m, 1H, $\mathrm{H}-3), 3.64\left(\mathrm{~m}, 2 \mathrm{H}, \mathrm{COCH}_{2}\right), 4.14\left(\mathrm{~m}, 2 \mathrm{H}, \mathrm{SOCH}_{2}\right), 5.31(\mathrm{~m}, 1 \mathrm{H}$, H-6), 7.33 (d, $J=8.0 \mathrm{~Hz}, 2 \mathrm{H}$, tosyl), 7.80 (d, $J=8.0 \mathrm{~Hz}, 2 \mathrm{H}$, tosyl). ${ }^{13} \mathrm{C}$ NMR $\delta_{\mathrm{C}}$ ppm: $12.02,18.90,19.49,21.24,21.78,22.71,22.96$, 24.01, 24.45, 28.17, 32.11, 28.17, 28.38, 32.11, 35.95, 36.38, 37.02, $37.27,39.05,39.70,39.97,42.51,50.35,56.37,56.96,66.56,69.81$, $79.79,121.95,128.17,129.92,140.77,144.82$.

$3 \beta$-(2-Azidoethoxy)cholest-5-ene, 9. The mixture of tosylate 8 (3.50 g, $6.0 \mathrm{mmol}), \mathrm{NaN}_{3}(3.25 \mathrm{~g}, 50 \mathrm{mmol}), \mathrm{DMF}(30 \mathrm{ml})$ was stirred for $2 \mathrm{~h}$ at a temperature of boiling water bath. After cooling the mixture was diluted with $120 \mathrm{ml}$ of benzene, filtered, the filtrate was washed with water $(3 \times 50 \mathrm{ml})$, dried over $\mathrm{Na}_{2} \mathrm{SO}_{4}$, and evaporated. The residue was crystallized from abs. EtOH to give $2.53 \mathrm{~g}(5.6 \mathrm{mmol}, 93 \%)$ of azide 9 as white cubes with m.p. $60^{\circ} \mathrm{C} .{ }^{1} \mathrm{H}$ NMR $\delta_{\mathrm{H}}$ ppm: 0.67 (s, 3H, H-18), 0.85 and 0.86 (each d, $J=6.6 \mathrm{~Hz}, 3 \mathrm{H}, \mathrm{H}-26$ and H-27), 0.91 (d, $J=6.6 \mathrm{~Hz}, \mathrm{H}-21), 1.00$ (s, $3 \mathrm{H}, \mathrm{H}-19), 3.20$ (m, 1H, H-3), 3.34 (m, $\left.2 \mathrm{H}, \mathrm{NCH}_{2}\right), 3.65(\mathrm{~m}, 2 \mathrm{H}$, $\left.\mathrm{COCH}_{2}\right), 5.34(\mathrm{~m}, 1 \mathrm{H}, \mathrm{H}-6) .{ }^{13} \mathrm{C} \mathrm{NMR} \delta_{\mathrm{C}} \mathrm{ppm}: 12.02,18.90,19.53$, 21.26, 22.71, 22.96, 24.01, 24.46, 28.17, 28.39, 28.49, 32.09, 32.12, $35.95,36.39,37.02,37.36,39.16,39.70,39.99,42.52,50.40,51.22$, $56.38,56.98,66.91,79.88,121.93,140.90$.

3ß-(2-Aminoethoxy)cholest-5-ene, 10. Azide 9 (1.55 g, $3.4 \mathrm{mmol}$ ) was dissolved in $15 \mathrm{ml}$ of abs. Et ${ }_{2} \mathrm{O}$, and solution obtained was added by drops to the stirred suspension of $\mathrm{LiAlH}_{4}$ $(0.66 \mathrm{~g}, 17.3 \mathrm{mmol})$ in $40 \mathrm{ml}$ of abs. $\mathrm{Et}_{2} \mathrm{O}$ at a speed required for boiling, thereafter the mixture was stirred under reflux for 30 min more. After cooling the excess of $\mathrm{LiAlH}_{4}$ was decomposed by adding of required amount of ice water, the ethereal solution was aspirated, the residue repeatedly extracted with $\mathrm{Et}_{2} \mathrm{O}$; the combined ethereal solution was dried over granulated $\mathrm{KOH}$, and evaporated to give aminosterol $\mathbf{1 0}$ in quantitative yield $(1.47 \mathrm{~g}$, $3.4 \mathrm{mmol}$ ) as a white waxy film, homogeneous according TLC, and indicated positive reaction with ninhyrdin. ${ }^{1} \mathrm{H}$ NMR $\delta_{\mathrm{H}}$ ppm: 0.67 (s, 3H, H-18), 0.85 and 0.86 (each d $J=6.6 \mathrm{~Hz}, 3 \mathrm{H}$, H-26 and H-27), 0.91 (d, $J=6.6 \mathrm{~Hz}, \mathrm{H}-21), 1.00$ (s, 3H, H-19), $3.20(\mathrm{~m}, 1 \mathrm{H}, \mathrm{H}-3), 3.34\left(\mathrm{~m}, 2 \mathrm{H}, \mathrm{NCH}_{2}\right), 3.65\left(\mathrm{~m}, 2 \mathrm{H}, \mathrm{COCH}_{2}\right)$, $5.34(\mathrm{~m}, 1 \mathrm{H}, \mathrm{H}-6) .{ }^{13} \mathrm{C}$ NMR $\delta_{\mathrm{C}} \mathrm{ppm}: 12.02,18.89,19.53,21.25$, $22.70,22.95,24.01,24.45,28.16,28.38,28.65,32.08,35.95$, $36.38,37.06,37.42,39.36,39.69,39.98,42.41,42.50,50.40$, $56.37,56.96,70.24,79.43,121.72,141.09$. 
17 "'[(Cholest-5-en)-3 $\beta-y$ loxyethoxycarbamoyl] pyropheophorbide $a, 1$. The mixture of pentafluorophenyl pheophorbide $a \mathbf{6}(70 \mathrm{mg}, 0.1 \mathrm{mmol})$ and aminosterol $10(128 \mathrm{mg}$, $0.3 \mathrm{mmol}$ ) in $10 \mathrm{ml}$ of abs. THF was stirred for $1 \mathrm{~h}$ at $40^{\circ} \mathrm{C}$, until the formation of target product was complete according to TLC and absorption spectrum. Thereafter the mixture was evaporated to dryness, passed through silica gel short column in $\mathrm{CH}_{2} \mathrm{Cl}_{2}$ containing $\mathrm{MeOH}(2 \% \mathrm{v} / \mathrm{v})$, and the product was finally purified by preparative TLC in $\mathrm{CH}_{2} \mathrm{Cl}_{2}$ containing $\mathrm{MeOH}(2 \% \mathrm{v} / \mathrm{v})$ to give target conjugate 1 ( $85 \mathrm{mg}, 0.09 \mathrm{mmol}, 90 \%$ ). HRMS, calculated for $\left[\mathrm{C}_{62} \mathrm{H}_{84} \mathrm{~N}_{5} \mathrm{O}_{3}\right]^{+}: 946.6496$, found: 946.6500. ${ }^{1} \mathrm{H}$ NMR $\delta_{\mathrm{H}}$ ppm: 0.45 and 0.65 (each s, $3 \mathrm{H}, \mathrm{H}-18$ and $\mathrm{H}-19$ in cholesterol moiety), 0.79 (d, $J=6.6 \mathrm{~Hz}, \mathrm{H}-21$ in cholesterol moiety), 0.87 and 0.88 (each d, $J=6.6 \mathrm{~Hz}, 3 \mathrm{H}, \mathrm{H}-26$ and $\mathrm{H}-27$ in cholesterol moiety), 1.57 (t, $J=7.2 \mathrm{~Hz}, 3 \mathrm{H}, \mathrm{CH}_{3} \mathrm{CH}_{2} \mathrm{C}=$ in pyropheophorbide moiety), 1.79 (d, $J=7.2 \mathrm{~Hz}, 3 \mathrm{H}, \mathrm{CH}_{3} \mathrm{CH}$ in pyropheophorbide moiety), 3.21 and 3.40 (each s, $3 \mathrm{H}, \mathrm{CH}_{3} \mathrm{CC}=$ in pyropheophorbide moiety), $3.54(\mathrm{~m}, 1 \mathrm{H}$, $\mathrm{H}-3$ in cholesterol moiety), 3.72 (br. $\mathrm{m}, 4 \mathrm{H}, \mathrm{CH}_{2}$ in aminoethoxy spacer $), 4.32(1 \mathrm{H}$, br. $\mathrm{m}, \mathrm{CCHC}=$ in pyropheophorbide moiety $)$, $4.53(1 \mathrm{H}, \mathrm{m}, \mathrm{CCHCCH}$ in pyropheophorbide moiety), $5.32(\mathrm{~m}, 1 \mathrm{H}$, H-6 in cholesterol moiety), 5.83 (br. 1H, NHCO), 6.15 (dd, $J=11.5$ $\mathrm{Hz}$ and $J=1.4 \mathrm{~Hz}, 1 \mathrm{H}, \mathrm{H}_{2} \mathrm{C}=\mathrm{CH}$, trans in pyropheophorbide moiety), 6.28 (dd, $J=17.7 \mathrm{~Hz}$ and $J=1.4 \mathrm{~Hz}, 1 \mathrm{H}, H_{2} \mathrm{C}=\mathrm{CH}$, cis in pyropheophorbide moiety), 7.97 (dd, $J=11.5 \mathrm{~Hz}$ and $J=17.7$ $\mathrm{Hz}, 1 \mathrm{H}, \mathrm{H}_{2} \mathrm{C}=\mathrm{CH}$ in in pyropheophorbide moiety), 8.53, 9.04, 9.35 (each $\mathrm{s}, 1 \mathrm{H}, \beta-\mathrm{H}, \mathrm{CHC}=$ in pyropheophorbide moiety). ${ }^{13} \mathrm{C} \mathrm{NMR} \delta_{\mathrm{C}}$ ppm: 11.29, 11.66, 12.16, 17.42, 18.66, 19.01, 19.40, 20.78, 22.64, $22.90,23.17,24.01,24.09,28.05,28.10,28.21,29.78,30.48,31.52$, $32.96,35.80,36.27,36.51,36.81,38.86,39.44,39.62,39.97,42.04$, 48.20, 49.71, 50.12, 51.91, 55.99, 56.24, 63.82, 66.13, 79.18, 93.10, $97.30,103.94,106.26,121.49,122.59,128.01,129.29,130.30$, $131.71,135.98,136.37,137.71,140.31,141.72,145.15,149.06$, $150.70,155.24,160.52,171.98,172.64,196.41$. UV-vis $\left(\mathrm{CH}_{2} \mathrm{Cl}_{2}\right)$ $\lambda_{\max } \mathrm{nm}: 398,498,660$.

13 '[(Cholest-5-en)-3 $\beta$-yloxyethoxycarbamoyl]chlorin $e_{6}$ 2. The mixture of methylpheophorbide $3(60 \mathrm{mg}, 0.1 \mathrm{mmol})$ and aminosterol $10(150 \mathrm{mg}, 0.33 \mathrm{mmol})$ in $4 \mathrm{ml}$ of abs. THF was incubated at $40^{\circ} \mathrm{C}$ for $48 \mathrm{~h}$, until the formation of target product was complete according to TLC. Thereafter the mixture was evaporated to dryness, passed through silica gel short column in $\mathrm{CH}_{2} \mathrm{Cl}_{2}$ containing $\mathrm{MeOH}(1 \% \mathrm{v} / \mathrm{v})$, and the product was finally purified by preparative TLC in $\mathrm{CH}_{2} \mathrm{Cl}_{2}$ containing $\mathrm{MeOH}(1 \% \mathrm{v} / \mathrm{v})$ to give target conjugate 2 (96 mg, 0,09 mmol, 90\%). HRMS, calculated for $\left[\mathrm{C}_{67} \mathrm{H}_{98} \mathrm{~N}_{5} \mathrm{O}_{6}\right]^{+}: 1068.7517$, found: $1068.7444 .{ }^{1} \mathrm{H}$ NMR $\delta_{\mathrm{H}} \mathrm{ppm}$ : -1.88 (broad s, $1 \mathrm{H}, \mathrm{NH}$ in chlorin $e_{6}$ moiety), $-1.40-1.90$ (broad, $1 \mathrm{H}, \mathrm{NH}$ in chlorin $e_{6}$ moiety), $0.64(\mathrm{~s}, 3 \mathrm{H}, \mathrm{H}-18$ in cholesterol moiety), 0.84 and 0.85 (each d, $J=6.6 \mathrm{~Hz}, 3 \mathrm{H}, \mathrm{H}-26$ and $\mathrm{H}-27$ in cholesterol moiety), 0.90 (d, $J=6.6 \mathrm{~Hz}, \mathrm{H}-21$ in cholesterol moiety), 0.93 (s, 3H, H-19 in cholesterol moiety), 1.71 (d, $J=7.2 \mathrm{~Hz}, 3 \mathrm{H}$, $\mathrm{CH}_{3} \mathrm{CH}$ in chlorin $e_{6}$ moiety), $1.72\left(\mathrm{t}, J=7.2 \mathrm{~Hz}, 3 \mathrm{H}, \mathrm{CH}_{3} \mathrm{CH}_{2} \mathrm{C}=\right.$ in chlorin $e_{6}$ moiety), 3.21 (m, $1 \mathrm{H}, \mathrm{H}-3$ in cholesterol moiety), 3.31 , $3.48,3.58,3.61$, and 3.71 (each $\mathrm{s}, 3 \mathrm{H}, \mathrm{CH}_{3} \mathrm{CC}=$ and $\mathrm{CH}_{3} \mathrm{OO}$ in chlorin $e_{6}$ moiety), 3.80 (q, $2 \mathrm{H}, J=7.5 \mathrm{~Hz}, \mathrm{CH}_{3} \mathrm{CH}_{2} \mathrm{C}=$ in chlorin $e_{6}$ moiety), $3.82\left(\mathrm{~m}, 2 \mathrm{H}, \mathrm{NCH}_{2} \mathrm{CH}_{2} \mathrm{O}\right), 4.03\left(\mathrm{~m}, 2 \mathrm{H}, \mathrm{NCH}_{2} \mathrm{CH}_{2} \mathrm{O}\right)$, $4.40\left(\mathrm{dd}, J=9.7 \mathrm{~Hz}\right.$ and $J=1.9 \mathrm{~Hz}, 1 \mathrm{H}, \mathrm{CH}_{3} \mathrm{CHCH}$ in chlorin $e_{6}$ moiety), 4.47 (q, $J=7.2 \mathrm{~Hz}, \mathrm{CH}_{3} \mathrm{CH}_{2} \mathrm{C}=$ in chlorin $e_{6}$ moiety), 5.29 $\left(\mathrm{d}, J=18.9 \mathrm{~Hz}, 1 \mathrm{H}, \mathrm{CCH}_{2} \mathrm{COO}\right.$ in chlorin $e_{6}$ moiety), $5.32(\mathrm{~m}, 1 \mathrm{H}$, H-6 in cholesterol moiety), 5.56 (d, $J=18.9 \mathrm{~Hz}, 1 \mathrm{H}, \mathrm{CCH}_{2} \mathrm{COO}$ in chlorin $e_{6}$ moiety), 6.13 (dd, $J=11.5 \mathrm{~Hz}$ and $J=1.4 \mathrm{~Hz}, 1 \mathrm{H}$, $H_{2} \mathrm{C}=\mathrm{CH}$, trans in chlorin $e_{6}$ moiety), $6.35(\mathrm{dd}, J=17.7 \mathrm{~Hz}$ and $J=1.4 \mathrm{~Hz}, 1 \mathrm{H}, H_{2} \mathrm{C}=\mathrm{CH}$, cis in chlorin $e_{6}$ moiety), 6.72 (broad m, $1 \mathrm{H}, H \mathrm{NCO}$ ), 8.07 (dd, $J=11.5 \mathrm{~Hz}$ and $J=17.7 \mathrm{~Hz}, 1 \mathrm{H}, \mathrm{H}_{2} \mathrm{C}=\mathrm{CH}$ in chlorin $e_{6}$ moiety), 8.80, 9.64, and 9.71 (each s, $1 \mathrm{H}, \beta-\mathrm{H}, \mathrm{CHC}=$ in chlorin $e_{6}$ moiety). ${ }^{13} \mathrm{C}$ NMR $\delta_{\mathrm{C}}$ ppm: $11.42,11.92,12.04,12.22$, $17.75,18.81,19.42,19.79,21.14,22.64,22.89,23.15,23.94,24.35$, $28.10,28.30,28.54,29.82,31.22,31.97,31.99,35.86,36.30,36.93$, $37.25,37.99,39.18,39.63,39.86,40.90,42.41,49.36,50.26,51.65$, $52.25,53.24,56.28,56.84,66.49,70.67,71.72,79.57,93.82,98.89$,
$101.46,102.58,121.58,121.72,121.87,128.51,129.60,130.12$, $130.27,134.72,134.92,135.01,135.30,136.07,139.05,140.72$, $144.73,148.84,153.92,166.94,169.02,169.44,173.56,173.81$. UV-vis $\left(\mathrm{CH}_{2} \mathrm{Cl}_{2}\right) \lambda_{\text {max }}$ nm: 398, 498, 660 .

Copper complexes of conjugates 11 and 12. Conjugate 1 or $2(20 \mathrm{mg}, 20 \mu \mathrm{mol})$ was dissolved in $2 \mathrm{ml}$ of $\mathrm{CH}_{2} \mathrm{Cl}_{2}$, the solution obtained was mixed with $6 \mathrm{ml}$ of $0.1 \mathrm{M}$ solution of $\mathrm{CH}_{3} \mathrm{COOCu}$ in $\mathrm{MeOH}$, and mixture was stirred at $40^{\circ} \mathrm{C}$ for $1 \mathrm{~h}$, until the reaction was complete according to absorption spectra. Thereafter, the mixture was evaporated to dryness and the residue was separated on a short silica gel column in $\mathrm{CH}_{2} \mathrm{Cl}_{2}-\mathrm{MeOH}$ (49:1) mixture, followed by additional purification on a TLC plate in the same system. The yields of both copper complexes were near to quantitative. 17" [(Cholest5-en)-3 $\beta$-yloxyethoxycarbamoyl]pyropheophorbide $a-\mathrm{Cu}$ complex 11: HRMS calculated for $\left[\mathrm{C}_{62} \mathrm{H}_{82} \mathrm{CuN}_{5} \mathrm{O}_{3}\right]^{+}: 1007.5708$, found: 1007.5770. 13'[(Cholest-5-en)-3b-yloxyethoxycarbamoyl] chlorin $e_{6}-\mathrm{Cu}$ complex 12: HRMS calculated for $\left[\mathrm{C}_{67} \mathrm{H}_{97} \mathrm{CuN}_{5} \mathrm{O}_{6}\right]^{+}$: 1129.6657, found: 1129.6620. Absorption spectra of copper complexes are shown in Figures 1 and 2.

Mixed vesicles of $P C$ containing conjugates 1, 2, 11 and 12. Chloroform solutions of $85 \mathrm{mg}(100 \mu \mathrm{mol})$ of egg yolk phosphatidylcholine (PC) and $2 \mathrm{mg}(2 \mu \mathrm{mol})$ of conjugate 1 (or 2) were mixed together, evaporated to dryness, and dissolved in 1 $\mathrm{ml}$ of ${ }^{\text {iso }} \mathrm{PrOH}$ at $50^{\circ} \mathrm{C}$ to obtain mixed solution containing $100 \mathrm{mM}$ of $\mathrm{PC}$ and $2 \mathrm{mM}$ of the conjugate. Aliquots of these solutions (30 $\mu \mathrm{l})$ were injected into $3 \mathrm{ml}$ of phosphate buffered saline at $37^{\circ} \mathrm{C}$ during wortexing. Mixed vesicles of PC with copper complexes of conjugates 11 and $\mathbf{1 2}$ were prepared using the same procedure. The vesicles obtained were used for determination of their stoichiometric compositions and measuring of absorption spectra (Figure 3) and EPR spectra (Figure 4). Stoichiometric compositions of PC vesicles containing conjugates $\mathbf{1}$ and $\mathbf{2}$ were determined as follows: $1 \mathrm{ml}$ of obtained vesicles was extracted with $\mathrm{CHCl}_{3} / \mathrm{MeOH}$ (2:1 by vol.) mixture $(3 \times 1 \mathrm{ml})$, followed by quantitative determination of PC concentration according to method ${ }^{[18]}$ and conjugates concentration from absorption spectra (suggesting $\varepsilon_{660}$ value for compounds $\mathbf{1}$ and $\mathbf{2}$, and $\varepsilon_{630}$ value for the corresponding copper complexes $\mathbf{1 1}$ and $\mathbf{1 2}$ to be equal to 36.000). The molar ratio of conjugate/ $\mathrm{PC}$ was found to be 1:50 in all cases.

\section{Results and Discussion}

The first task was the synthesis of cholesterol derivative suitable for coupling with macrocycles. 3 $\beta$ (2-Hydroxyethoxy) cholest-5-ene $7^{[15,16]}$ was used as starting compound. For the introduction of amino group the common sulfonate - azide procedure was used (Scheme 1): treatment of compound 7 with $\mathrm{TsCl}$ in Py gave tosylate 8 in $89 \%$ yield; subsequent substitution of tosyloxy group for azide by heating with excess of $\mathrm{NaN}_{3}$ in DMF led to the formation of compound 9 in high yield; and finally azide 9 was reduced to target aminosterol 10 by treatment with $\mathrm{LiAlH}_{4}$ in $\mathrm{Et}_{2} \mathrm{O}$.

Methyl pheophorbide $a \mathbf{3}$, obtained according to the reported procedure ${ }^{[14]}$ was used as macrocycle containing building block. The synthetic pathway, which led to the target conjugates $\mathbf{1}$ and $\mathbf{2}$ and their copper complexes $\mathbf{1 1}$ and 12, is shown in Scheme 2.

The presented scheme for the synthesis of conjugate 1 required preparation and using the macrocycle containing activated ester $\mathbf{6}$. We have modified the reported procedure ${ }^{[17]}$ for decarbmetoxylation of methylpheophorbide $a \quad \mathbf{3}$ : methylpyropheophorbide a $\mathbf{4}$ was obtained in $90 \%$ yield by heating of compound 3 in boiling pyridine for $8 \mathrm{~h}$. The resulting ester 4 was then subjected to hydrolysis in aqueous sulfuric acid to obtain pyropheophorbide $\mathbf{5}$ in quantitative 
<smiles>CC(C)CCCCC(C)C(C)CCC12CCC3C(CC=C4CC(OCCO)CCC43C)C1CCC2C(C)CCCC(C)C</smiles>

Scheme 1.
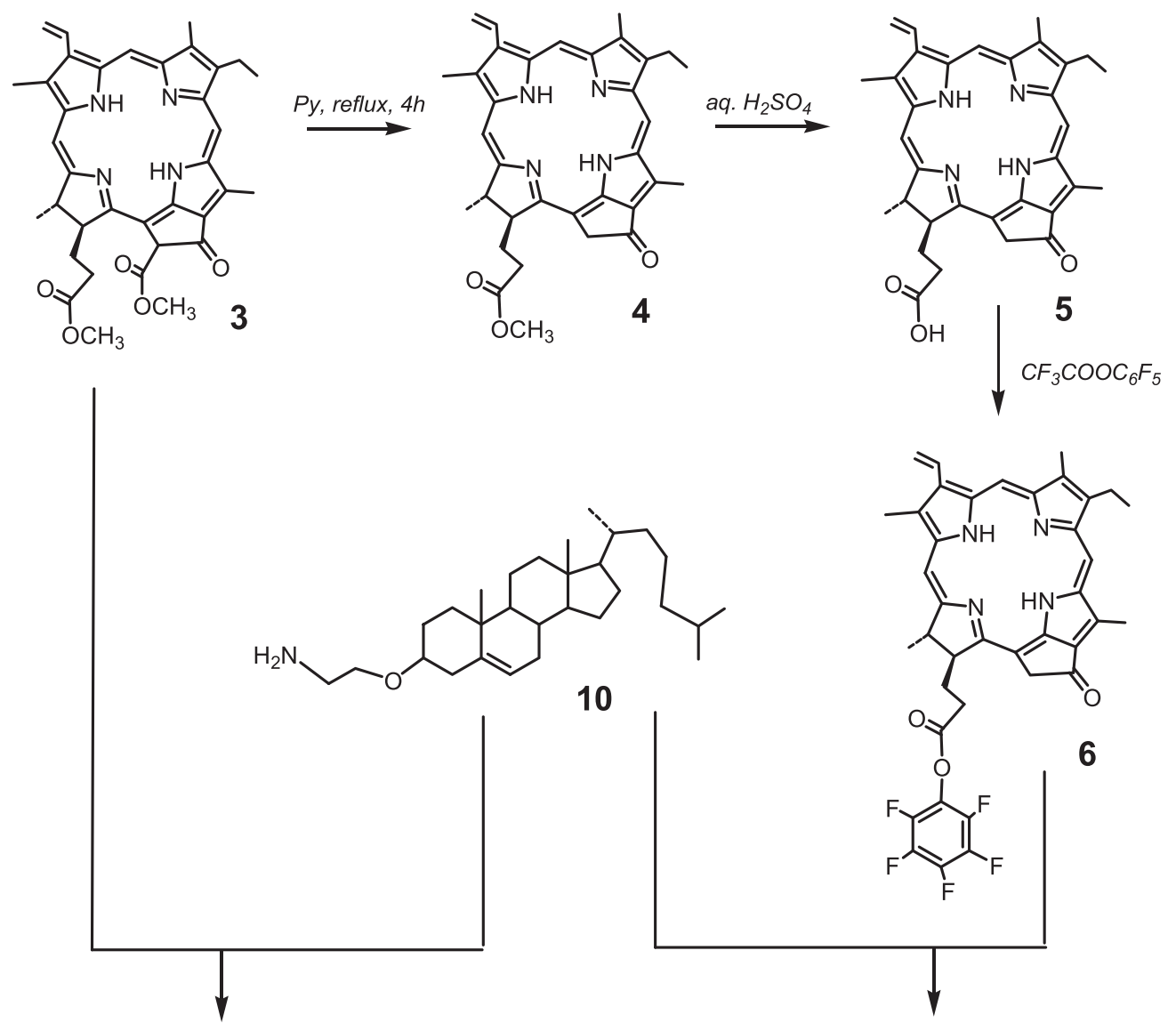

(2)

(1)

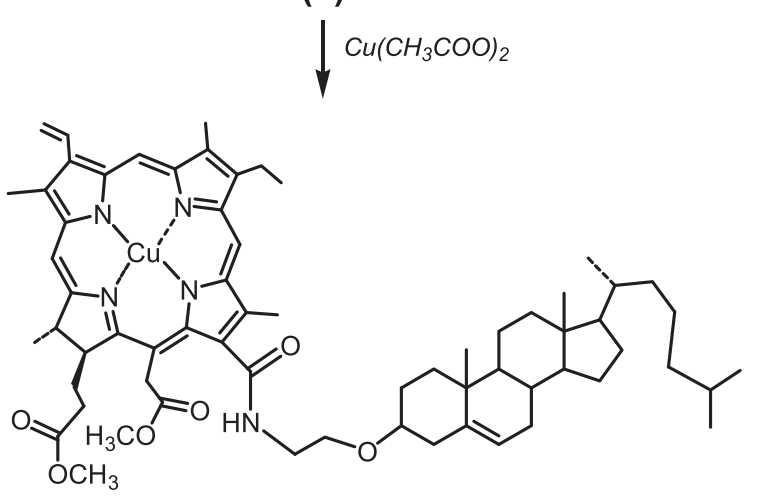

12

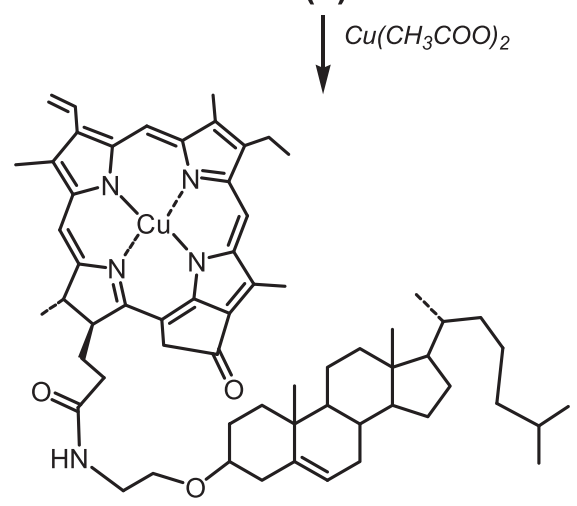

11

Scheme 2. 
yield. Finally, the treatment of acid $\mathbf{5}$ with pentafluorophenyl trifluoroacetate in the presence of Et ${ }_{3} \mathrm{~N}$ gave pentafluorophenyl pyropheophorbide $a \mathbf{6}$ in a quantitative yield. Compound $\mathbf{1}$ was obtained via substitution of pentafluorophenyl group in compound $\mathbf{5}$ for aminosterol $\mathbf{1 0}$ in warm THF in the presence of $\mathrm{Et}_{3} \mathrm{~N}$ in $90 \%$ yield.

For the preparation of conjugate 2 the known reaction of nucleophilic opening of exocycle E in methyl pheophorbide $a \mathbf{3}$ by amines was used: ${ }^{[19]}$ incubation of compound $\mathbf{3}$ with 3 equivalents of aminosterol 10 in $\mathrm{THF}$ at $40^{\circ} \mathrm{C}$ for $48 \mathrm{~h}$ led to the target amide conjugate $\mathbf{2}$ isolated in $90 \%$ yield.

Both conjugates $\mathbf{1}$ and $\mathbf{2}$ were isolated as individual compounds according to TLC, their structures were completely characterized by HRMS, ${ }^{1} \mathrm{H}$ NMR, ${ }^{13} \mathrm{C}$ NMR and absorption spectra. ${ }^{1} \mathrm{H}$ NMR spectra of compounds $\mathbf{1}$ and $\mathbf{2}$ demonstrated significant differences in orientation of their steroid backbone regarding to macrocycle. We observed extraordinary low values for chemical shifts for exocyclic methyl protons occupying $\beta$-region of sterol moiety in compound 1. Namely, cholersteryl H-18 and H-19 protons in compound 1 exhibited chemical shifts values of $0.45 \mathrm{ppm}$ and $0.67 \mathrm{ppm}$, respectively, while those in compound 2 (0.64 ppm and $0.93 \mathrm{ppm}$, respectively) were in common range for cholesterol derivatives. We speculate that observed high field shifts of $\mathrm{H}-18$ and $\mathrm{H}-19$ protons in compound 1 were due to their proximity to inner core of macrocycle.

Conjugates $\mathbf{1}$ and $\mathbf{2}$ form copper complexes in quantitative yields, being heated with excess of $\mathrm{Cu}\left(\mathrm{CH}_{3} \mathrm{COO}\right)_{2}$ in $\mathrm{CH}_{2} \mathrm{Cl}_{2}-\mathrm{MeOH}$ mixture $(1: 3)$ for $1 \mathrm{~h}$, with subsequent isolation of resulting copper complexes 11 and 12 by silica gel flash chromatography. The structure of complexes $\mathbf{1 1}$ and $\mathbf{1 2}$ was confirmed by characteristic HRMS peaks corresponding to molecular ions, as well as by absorption spectra and EPR spectra.

The absorption spectrum of conjugate $\mathbf{1}$ in $\mathrm{CH}_{2} \mathrm{Cl}_{2}$ (spectrum 1, Figure 1) was typical for those of chlorins containing cyclopentanone ring. The main long wave maximum revealed at $668 \mathrm{~nm}$, and slightly split Soret band - at $414 \mathrm{~nm}$ (with shoulder at $398 \mathrm{~nm}$ ). Protonated form of this compound (spectrum 2, Figure 1), obtained by adding of trifluoroacetic acid (TFA), had long way maximum at 652 $\mathrm{nm}$ and considerably more intensive Soret band shifted to

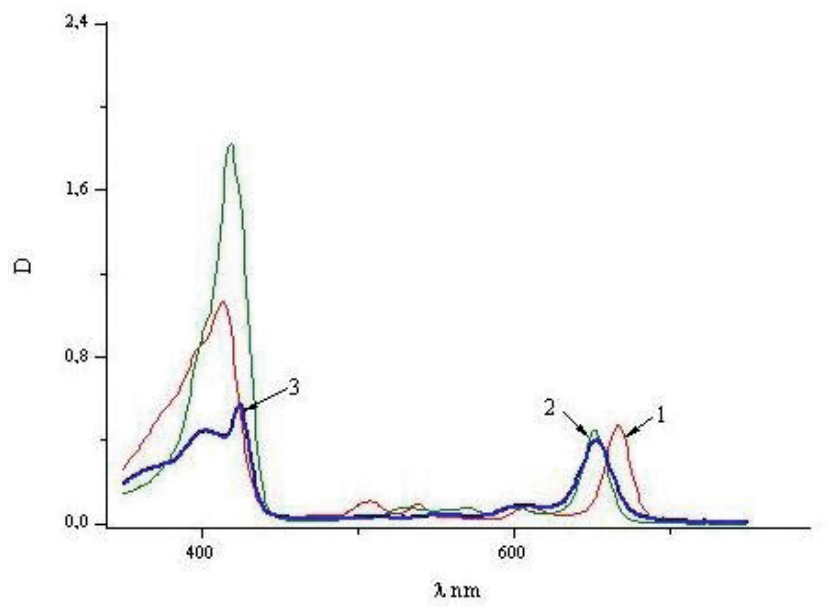

Figure 1. Absorption spectra of conjugate 1 and related copper complex 11: 1 - solution of conjugate 1 in $\mathrm{CH}_{2} \mathrm{Cl}_{2} ; 2$ - the same in the presence of TFA traces; 3 - solution of copper complex $\mathbf{1 1}$ in $\mathrm{CH}_{2} \mathrm{Cl}_{2}$.
$419 \mathrm{~nm}$. A comparison of the spectral changes of conjugate 1, caused by either its protonation (spectrum 2, Figure 1), or formation of its copper complex 11 (spectrum 3, Figure 1), indicated close hypsochromic shifts for their long way maxima (652 $\mathrm{nm}$ and $654 \mathrm{~nm}$, respectively), but quit different changes in their Soret bands. A Soret band in copper complex 11 (spectrum 3, Figure 1) had a maximum at $425 \mathrm{~nm}$ and was considerably split; their intensity was seemed to be one third as compared to the protonated form of compound 1 (spectrum 1, Figure 1).

The long wave maximum for compound 2 in $\mathrm{CH}_{2} \mathrm{Cl}_{2}$ $(660 \mathrm{~nm})$ was usual for chlorin $e_{6}$ derivatives, it exhibited hypsochromic shift to $633 \mathrm{~nm}$ when copper complex 12 was derived. Additionally, formation of copper complex 12 led to the considerable bathochromic shift of Soret band, this band was slightly split and revealed maxima at 398, 399 and $410 \mathrm{~nm}$ (Figure 2).

Both conjugates $\mathbf{1}$ and $\mathbf{2}$, as well as the corresponding copper complexes $\mathbf{1 1}$ and 12, may be simply incorporated in phospholipids bilayers. Mixed vesicles, consisted of egg yolk phosphatidylcholine (PC) and aforementioned conjugates, were prepared according to known procedure ${ }^{[20]}$ developed earlier for the preparation of unilamellar vesicles from pure $\mathrm{PC}$, and $\mathrm{PC}-$ cholesterol mixtures. Incorporation of conjugates 1, 2, 11 and $\mathbf{1 2}$ into vesicles provides their

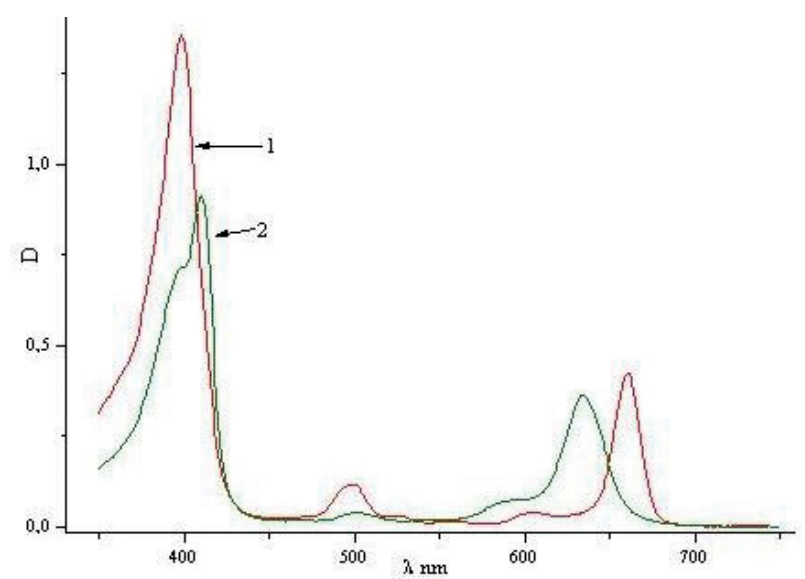

Figure 2 Absorption spectra of conjugate 2 and related copper complex 12: 1 - solution of conjugate 2 in $\mathrm{CH}_{2} \mathrm{Cl}_{2} ; 2$ - solution of copper complex 12 in $\mathrm{CH}_{2} \mathrm{Cl}_{2}$.

solubilization in aqueous medium, and leads to the notable changes in absorption spectra when compared with these of $\mathrm{CH}_{2} \mathrm{Cl}_{2}$ solutions (Figure 3). Being entrapping in $\mathrm{PC}$ vesicles, these compounds exhibited long wave maxima about $6-8 \mathrm{~nm}$ lower than that in $\mathrm{CH}_{2} \mathrm{Cl}_{2}$ solution. Probably, it is caused by association of chromophores in lipid bilayer. These bathochromic shifts, apparently caused by increasing of the medium polarity, thus confirming the dye exposure on the bilayer surface, were observed for Soret bands as well.

Important information concerning binding of conjugates to phospholipids may be obtained from analysis of EPR spectra of the corresponding copper complexes. EPR spectra of conjugate $\mathbf{1 2}$ powder (Figure 4A, spectrum 1) and $\mathrm{PC}$ vesicles containing conjugate $\mathbf{1 2}$ in aqueous solution (Figure 4A, spectrum 2) look similar to well-known ones for porphine-like copper complexes. ${ }^{[21]}$ High-field perpendicular manifold splits into two major components due to second- 


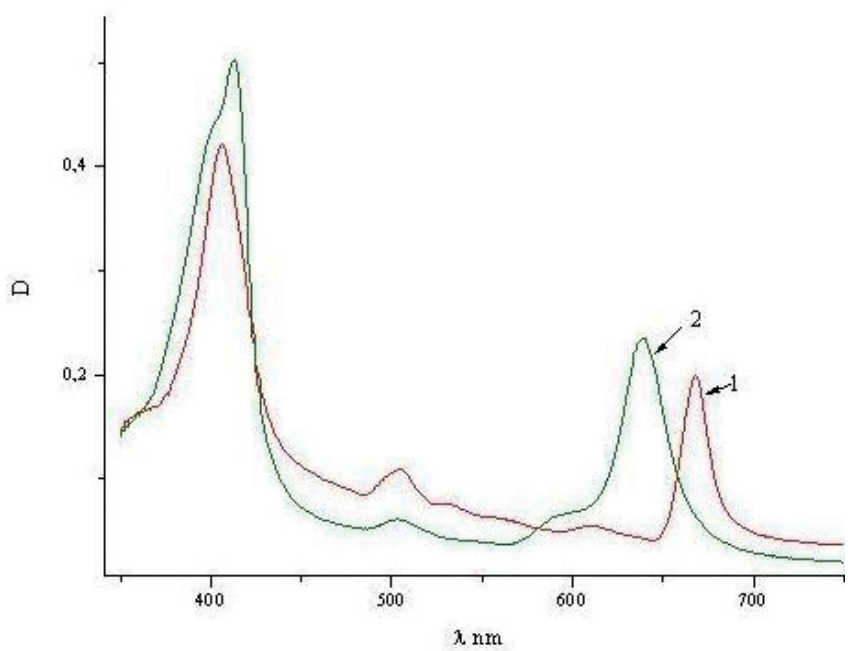

Figure 3. Absorption spectra of conjugate $\mathbf{2}$ and copper complex 12 entrapped in PC vesicles: 1 - mixed vesicles 2-PC in aqueous solution, $\mathrm{pH}$ 7.4; 2 - mixed vesicles $12-\mathrm{PC}$ in aqueous solution, $\mathrm{pH} 7.4$.

order effects ('angular anomalies'), ${ }^{[22]}$ and this is typical for systems with highly anisotropic spin Hamiltonian. Angles about $70^{\circ}$ (with respect to magnetic field) contribute mainly to the most high-field component, ${ }^{[2]}$ thus providing some spatial resolution in perpendicular region. Splitting between lowfield peaks (referenced as $A$ parameter, Figure 4A) provides a measure of motional spectrum narrowing. In rigid-limit state (no motion, with correlation times much larger than spin Hamiltonian anisotropy) it is equal to parallel component of ${ }^{63} \mathrm{Cu}$ nucleus hyperfine tensor (typically about 200G), while motions comparable to hyperfine tensor anisotropy leads to decreasing of $A$ value.

Compared to EPR spectrum of conjugate 12 in $\mathrm{CH}_{3} \mathrm{Cl}$ solution (Figure 4B), the spectrum of the same complex in $\mathrm{PC}$ vesicles (Figure 3A, spectrum 2) displays much higher value of A (209.7G vs. 110.6G). This clearly confirms an entrapping of conjugate into $\mathrm{PC}$ vesicles, because of $\tau_{\text {(free conjugate) }}<<\tau_{\text {(vesicle) }}$. Moreover, the value of $A$ at $293 \mathrm{~K}$ for PCentrapped complex is even larger than in powder spectrum of free one $(209.7 \mathrm{G}$ vs. $201.5 \mathrm{G})$, approaching rigid-limit
(211.9G, as measured at $77 \mathrm{~K}$ ) indicating intramolecular fast oscillations being hindered by the bilayer. This allows relating membrane director tilt angles with hyperfine splitting.

Additionally, in powder spectrum of conjugate 12 (Figure 4A, spectrum 1), the super-hyperfine splitting in the region of perpendicular manifold (arising from four nitrogen nuclei of chlorin ring) is almost unresolved, while in the presence of PC it is clearly emphasized. Therefore, an entrapping of the cholesterol moiety of conjugate into PC vesicle, leads to the exposure of its macrocycle ring on the surface of bilayer, hindering its reorientational motion, and preventing copper centers from spin-spin interaction due to spatial separation, which otherwise leads to the line broadening.

\section{Conclusions}

The presented results demonstrated that modification of macrocycle with cholesterol fragment led to novel conjugates exhibiting affinity to phospholipids. Being incorporated in PC vesicles, these conjugates are efficiently taken up by the cultured cells (preliminary results obtained in our lab), enabling them to be considered as a novel potential sensitizers for photodynamic therapy. Being used as the spin probes, the conjugates containing paramagnetics, may provide an important structural and dynamical information.

Acknowledgements. This study was supported by Russian Foundation for Basic Research (grant 09-04-00454-a).

\section{References}

1. Licha K., Schirner M., Henry G. Handb. Exp. Pharmacol. 2008, 185 (Pt.1) 203-222.

2. Perfetto S.P., Chattopadhyay P.K., Roederer M. Nature Rev. Immunol. 2004, 4, 648-655.

3. Hamblin M.R., Hasan T. Photochem. Photobiol. Sci. 2004, 3, 436-450.

4. Pandey R.K., Zheng G. In: The Porphyrin Handbook (Kadish K.M., Smith K.M., Guilard R., Edrs.). San Diego: Academic Press, CA, 2000, Vol. 6, pp. 157-230.
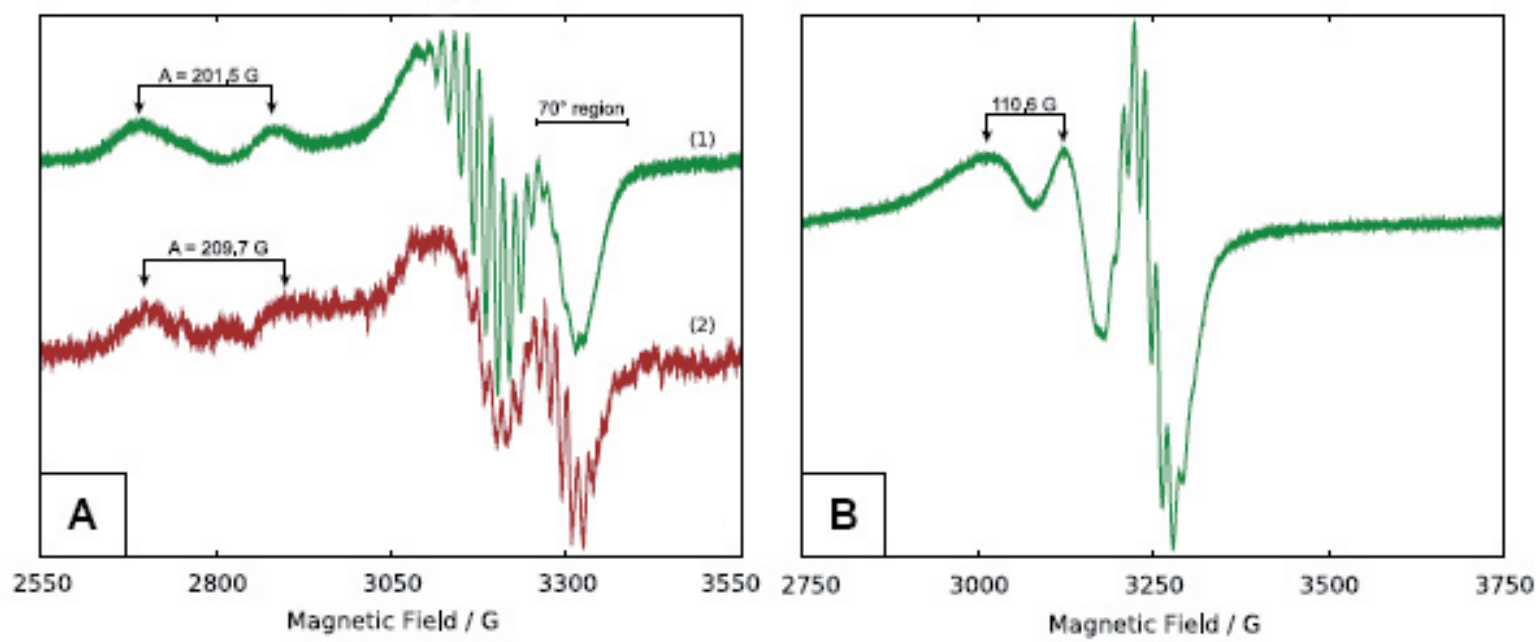

Figure 4. X-band EPR spectra of conjugate 12. (A): 1 - solid-state powder spectrum of conjugate 12; 2 - spectrum of conjugate 12-PC mixed vesicles in aqueous solution, $\mathrm{pH} 7.4$; (B) - spectrum of conjugate 12 in $\mathrm{CHCl}_{3}$ solution. 
5. Bonnett R. Chemical Aspects of Photodynamic Therapy. Amsterdam: Gordon and Breach Science, 2000, 305 p.

6. Detty M.R., Gibson S.L., Wagner S.J. J. Med. Chem. 2004, 47, 3897-3915.

7. Fan D., Taniguchi, M., Yao, Z., Dhanalekshmi S., Lindsey J.S. Tetrahedron 2005, 61, 10291-10302.

8. Muresan A.Z., Lindsey J.S. Tetrahedron 2008, 64, 1144011448.

9. Leroux J., Roux E., Le Garrec D., Hong K., Drummond D.C. J. Control Release 2001, 72, 71-84.

10. Polo L., Bianco G., Reddi E., Jori G. Int. J. Biochem. Cell Biol. 1995, 27, 1249-1255.

11. Zheng G., Li H., Zhang M., Lund-Katz S., Chance B., Glickson J.D. Bioconjugate Chem. 2002, 13, 392-396.

12. Khan E.H., Ali H., Tian H., Rousseau J., Tessier G., Shafiullaha, van Lier J.E. Bioorg. Med. Chem. Lett. 2003, 13, 1287-1290.

13. Nikolaeva I.A., Misharin A.Yu., Ponomarev G.V., Timofeev V.P., Tkachev Ya.V. Bioorg. Med. Chem. Lett. 2010, 20, 28722875 .
14. Wongsinkongman P., Brossi A., Wang H.-K., Bastow K.F., Lee K.-H. Bioorg. Med. Chem. 2002, 10, 583-591.

15. Misharin A.Yu., Malugin A.V., Steinschneider A.Ya., Kosykh V.A., Novikov D.K., Med. Chem. Res. 1993, 3, 451-458.

16. Malugin A.V., Novikov D.K., Kosykh V.A., Kosenkov E.I., Medvedeva N.V., Valentinova N.V., Steinschneider A.Ya., Misharin A.Yu. Bioorgan. Khimia 1996, 22, $541-547$ (in Russ.).

17. Panday R.K, Dougherty T.J., Pallenberg A.J. US Pat. 7053210 / Issued on May 302006 / Efficient Synthesis of Pyropheophorbide $a$ and its Derivatives.

18. Vaskovsky V.E., Kostetsky E.V., Vasendin I.M. J. Chromatogr. 1975, 114, 129-141.

19. Ellsworth P.A., Storm C.B. J. Org. Chem. 1978, 43, 281-283.

20. Batzri S., Korn D.E. Biochim. Biophys. Acta 1973, 298, 10151018.

21. Bohandy J., Kim B.F. J. Magn. Reson. 1977, 26, 341-349.

22. Rollman L.D., Chan S.I. J. Chem. Phys. 1969, 50, 34163431. 